\title{
AIUNT NON VOS ESSE PAPAM, SED ME. SVÄTÝ BERNARD, RÍMSKI BISKUPI A PÁPEŽSTVO V ZRKADLE KOREŠPONDENCIE ${ }^{1}$
}

\author{
Aiunt non vos esse Papam, sed me. \\ Saint Bernard, Roman Bishops and Papacy Mirrored in Correspondence
}

\author{
Dušan Zupka
}

DOI: 10.17846/CL.2020.13.2.76-88

\begin{abstract}
ZUPKA, Dušan. Aiunt non vos esse Papam, sed me. Saint Bernard, Roman Bishops and Papacy Mirrored in Correspondence. Bernard of Clairvaux (1090 - 1153) belongs to the most important historical figures of the first half of the twelfth century. Almost 500 letters were preserved form his monumental works until today. These letters were sent to most important personalities of the secular and spiritual world of his day. This article seeks to analyse and interpret the relation of Saint Bernard with popes as leader of the Catholic Church and with the papacy as an institution destined to lead the faithful to the eternal salvation. The abbot of Clairvaux kept vivid contacts with all the popes reigning between 1124 and 1153. In the case of Innocent II and Eugene III one can say that he even actively enabled their instalment on the throne of St. Peter. Just like in the case of monasticism, episcopate or lay princes, Bernard took a similar approach towards the popes. He enforced his vision of the papacy. Bernard was also able to transform these visions to real life and so he exercised a double impact on the most important institution of the Christian world.
\end{abstract}

Keywords: Bernard of Clairvaux, papacy, correspondence, church reform, cistercians, Innocent II, Eugenius III

Máloktorá osobnost' ovplyvnila duchovné, kultúrne, no v neposlednom rade aj politické dejiny Európy v prvej polovici 12. storočia tak výrazne ako svätý Bernard (1090 - 1153). Ten sa stal opátom cistercitského kláštora v burgundskom Clairvaux v roku 1113. Po dobu štyroch desatročí, až do svojej smrti, zostal neúnavným bojovníkom za cirkev, svoj reholný rád, ako aj vplyvnou duchovnou osobnostou krestanského Západu. ${ }^{2} \mathrm{~V}$ literatúre je často označovaný za najmocnejšieho muža svojej doby (Duby 1979, 10; Le Goff 1985, 50), človeka stelesňujúceho renesanciu 12. storočia (Davy 2001, 17), ktoré tiež nazývajú storočím sv. Bernarda (Leclercq 1998, 109; Verger - Jolivet 2006, 180-183). Stal sa hlavným predstavitelom cistercitov, bol ich najznámejšou osobnostou a dokázal si získat mocných a vplyvných priatelov. Práve tieto jeho kontakty a oddanost vysokých

Táto štúdia bola podporená Agentúrou na podporu výskumu a vývoja na základe zmluvy č. APVV - 18 0333 Databáza historickej terminológie k dejinám Strednej Európy, projektom VEGA 1/0814/18 Dejiny diplomacie $v$ ranom stredoveku a KEGA 004UKF-4/2018 Európsky stredovek interaktívne.

2 Literatúra $\mathrm{k}$ životu a dielu sv. Bernarda je mimoriadne rozsiahla. Opát z Clairvaux bol totiž predmetom záujmu historikov už počas svojho života a tento trend neochabol dodnes. Štandardné všeobecné spracovania ponúkajú Joseph Calmette (1979), Pierre Aubé (2003) a Adriaan H. Bredero (1996). 
cirkevných i svetských hodnostárov boli dôležitým klúčom k úspechu Bernardovho pôsobenia. Spojovníkom s Rímom bol Burgundan, kancelár Haimeric, na biskupskom stolci v Châlons bol priatel' a učitel' Viliam zo Champeaux, biskupom v Langres sa stal Bernardov bratranec Godefroi de la Roche, priatelmi mu boli aj sv. Norbert, arcibiskup v Magdeburgu, Malachiáš, biskup v írskom Armaghu, Hugo z Mâconu biskup v Auxerre, Suger, opát zo St. Denis, opát Viliam zo St. Thierry, teológovia Hugo a Richard zo Sv. Viktora pri Parízi a d’alši. ${ }^{3}$ Úlohou a snahou každého významného cirkevného autora bolo definovanie cirkvi a načrtnutie vlastnej vízie a chápania tejto inštitúcie. Vela informácii sa dozvedáme z obsiahleho korpusu spisov, kázni a listov, v ktorých Bernard z Clairvaux reflektoval svoju dobu podobne ako pred ním naposledy sv. Augustín. ${ }^{4}$ V tomto príspevku sa pokúsime zrekonštruovat svätcove názory na rímskych biskupov a inštitúciu pápežstva tak, ako ju vykreslil vo svojej bohatej korešpondencii. ${ }^{5}$ Tá sa považuje za najoriginálnejšiu čast' Bernardovho diela, ktorá svojou priamostou a úprimnostou najlepšie vystihuje jeho skutočné myšlienky (McGuire 2011, 3).

\section{Postgregoriánske pápežstvo a opát z Clairvaux}

Ako reholník sa Bernard z Clairvaux dostával do každodenného kontaktu s predstavitelmi miestnej cirkvi, ako opát rozvíjajúceho kláštora zase musel udržovat vztahy s okolitými biskupmi, no a ako verejne a literárne činný vzdelanec komunikoval aj s pápežmi. Cisterciti podliehali vd’aka zvláštnemu privilégiu pod ochranu rímskeho biskupa a boli oslobodení od platenia desiatkov. Táto naviazanost' na kúriu je badatelná i na samom Bernardovi, ktorý počas svojho pôsobenia udržoval korešpondenciu so všetkými šiestimi pápežmi medzi rokmi 1124 - 1153. S mnohými sa aj osobne poznal. Pre Inocenta II. bojoval osem rokov o jeho uznanie proti Anakletovi a Inocentov nástupca Eugen III. bol jedným z Bernardových najbližších priatelov v Clairvaux. Okrem toho, čo bolo pre cistercitov typické (Barraclough 1968, 90), bol náročným pozorovatelom a kritikom diania v Ríme, hlavne pokial išlo o novozavádzané praktiky, prílišnú zameranost̉ na právne úkony či vlažnosṫ v liturgických povinnostiach pápeža. V neskorších rokoch, už ako uznávaná autorita, pomáhal Bernard aktívne formovat inštitút Petrovho nástupcu a priamo ovplyvňoval mnohé rozhodnutia kúrie. ${ }^{6}$

Po rokoch dlhých bojov, ktoré od pontifikátu Gregora VII. (1073 - 1085) zvádzala rímska cirkev s nemeckými cisármi, i vo vlastných radoch, sa po uzavretí mieru Wormským konkordátom roku 1122 začína nová éra postgregoriánskej reformy. Tieto snahy sú vel’mi dobre symbolizované návratom k pôvodným menám pápežov z čias ranej cirkvi. Počínajúc Urbanom II. od roku 1088 nastupujú Paschalis, Gelasius, Kalixtus, Honorius, Inocent, Celestín a Lucius, všetci s poradovým číslom II. Všetky tieto kroky vonkajšej i vnútornej premeny vedú postupne k centralizácii a monarchizácii

3 Kardinál Haimeric bol doslova „pravou rukou“ Bernarda v rímskej kúrii. Opát z Clairvaux bol zároveň jeho duchovným radcom. Venoval mu napríklad svoje dielo O láske k Bohu (Béguin 1953, 27). K ostatným kontaktom pozri (Jedin 2000, 4890-4892).

4 Bernardovo súborné dielo patrí k najrozsiahlejším v dejinách krestanstva. Všetky práce sú vydané v klasickej edícii J. P. Mignea (Patrologia Latina, tom. 182-185) a v modernom vydaní editorov Leclerq-Talbot-Rochais (Sancti Bernardi Opera 1957-1958).

5 Vydané v Patrologia Latina (Tom. 182, col. 1-367). V súčasnosti sa prevažne používa moderné štandardné vydanie B. S. Jamesa. (James, Letters 1998). Listy citované v tomto príspevku sa pridržiavajú číslovania jeho edície.

6 Zhrňujúcou prácou, ktorú opát napísal pre potrebu práve zvoleného Eugena III., je jeho známe dielo $O$ rozvažovaní (De consideratione). My sa však obmedzíme len na názory prezentované v Bernardovej bohatej korešpondencii. 
pápežstva, ktoré dosiahne svoj vrchol na sklonku 12. storočia v pontifikáte Inocenta III. (1198 1216) (Franzen 2006, 138-169; Sayers 1994).

Práve tento trend posilňovania moci rímskeho biskupa, dôslednejšie presadzovanie jeho autority i v odlahlých častiach Európy pomocou pápežských legátov, úzka spolupráca s reformnými mnišskymi rádmi a istota $\mathrm{v}$ možnosti spolahnutia sa na diecéznych biskupov, vytvárali priaznivé podmienky pre vzostup inštitúcie, ktorá by zaujala vedúcu úlohu v duchovnom, kultúrnom, no stále viac i v právno-politickom dianí Európy. ${ }^{7}$

\section{Kristov námestník}

Bernard z Clairvaux bol citlivým pozorovatelom týchto zmien a zároveň $\mathrm{k}$ nim zaujímal stanovisko vo svojich dielach a listoch. Okrem popisovania súčasného stavu, kritizovania neduhov či chvály dobrých krokov, môžeme v jeho korešpondencii postrehnút aj vytváranie určitého modelu - dokonalého Petrovho nástupcu (resp. Kristovho námestníka, Bohom posväteného, biskupa národov, najvyššieho kňaza). Tak ako vo všetkom, aj v tomto prípade hladá opát inšpiráciu vo Svätom písme a kladie dôraz najmä na apoštolskú tradíciu, ktorej priamym pokračovatelom je práve rímsky biskup.

Zo starozákonnej tradície je pápežovi najvhodnejším príkladom či predobrazom postava dobrého služobníka Božieho, ktorý je zároveň akoby otcom celého národa. Podobne ako v tažkých časoch Boh vybral pre biblický vyvolený národ pomazaného služobníka, tak aj súčasný krestanský lud potrebuje ochrancu a milujúceho otca, čo povedie svojich verných. Jeden príklad za všetky predstavuje práve král' Dávid:

Nezabudol som na Božie rozhodnutia v dávnych časoch, alebo o ktorých vraví Písmo, ked’ vela mužov bolo Božou vôlou vzatých zo súkromného či dokonca vidieckeho života, aby vládli jeho ludu. Aby som spomenul len jedného, nevybral si Dávida podobným spôsobom, aby bol jeho služobníkom...? (List 237)

Pápež si má byt vedomý svojho výnimočného postavenia a úlohy, ktorou ho Boh poveril, zároveň však nesmie svoj post zneužívat a vždy musí brat hlavne ohlad na svojich blízkych. Jeho právomoc daná zhora je však pomerne široká, no také sú i nároky na jej držitela. Post rímskeho biskupa je postom vysokým, ale zároveň neistým, vznešeným, ale taktiež nebezpečným, jedným slovom teda hrozné miesto (terribilis locus) (List 238).

Základom postavenia a vplyvu pápeža vo svete bola jeho prirodzená autorita, ktorú požíval ako nástupca svätého Petra, priamo ustanoveného za pastiera krestanov Kristom. Táto autorita mu umožňovala jednat rovnocenne so všetkými cirkevnými a svetskými predstavitelmi, vrátane biskupov a panovníkov, a zároveň mu dodávala určitú výhodu oproti nim. V postupne sa vytvárajúcej stredovekej christianitas požíval pápež stále väčšiu vážnost̉ a bol symbolickým i skutočným pánom. ${ }^{9}$

7 Podrobnejšie k tomuto procesu Barber (1993, 85-101); Collins (2009, 220-244); Hehl et al. (2002, 9-23; 243-262).

8 „Sed nec ego oblitus sum judiciorum Dei antiquorum, et Scripturae plurimos recensentis ex privata seu etiam rusticana vita olim assumptos in voluntate Domini ad regendum populum ejus. Denique nonne (ut unum e pluribus memorem) tali quodam modo elegit David servum suum [...]“. List napísaný roku 1145 pri príležitosti zvolenia Bernarda z Pisy za pápeža Eugena III.

9 Azda najlepšie spracovanie tejto problematiky podal vo svojej prelomovej práci Robert Bartlett (1994, 243-268). 
Bernard ako každý, túto autoritu rešpektoval. No zdôrazňuje, že i ten najlepší či najmocnejší pápež sa musí podrobit autorite Najvyššieho velkňaza (summus Pontifex), teda samotného Krista. Žiadny čin ani nariadenie nie sú správne, ked’odporujú Kristovmu učeniu, a teda to, čo je zlé, nemôže sa legalizovat pápežským dovolením, lebo je zlom súhlasit so zlom. ${ }^{10}$ Takéto dodatočné zakrývanie zlých skutkov na základe (často vynútených) povolení od rímskeho biskupa je však len neúčinným a zúfalým pokusom o potretie vlastnej hanby tak, ako sa o to pokúšali Adam a Eva s figovým listom. Ked' Ježiš učil, aby „sa nikto neopovážil pohŕdat týmito maličkými, ktorí vo mňa veria“(Mt 23-10,6), nedodal k tomu „pokial nemáte pápežské povolenie“(List 7). ${ }^{11}$

Bernard však nezostáva len pri pomenovaní toho, čo pápež nesmie a čím má byt jeho konanie ohraničené. Venuje sa aj tomu, čo by malo byt pre rímskeho biskupa najdôležitejšie, jeho hlavným povinnostiam a jeho postaveniu vo svete. Svojím povýšením sa má vžit do úlohy milujúceho otca tak, ako pred ním Abrahám, Jakub, Peter a Pavol (List 238). Ako ženích cirkvi musí neustále pomáhat chudobným a blížnym, očakáva sa od neho, že sa bude starat o ludí, a nie o zlato, že bude dohliadat' na ríše a ničit všetko zlo. Aby mohol tieto povinnosti plnohodnotne plnit', musí byt' odvážny a dobrého srdca, pamätat na to, že je len človek a bát sa Boha, brat si príklad z vrtkavosti osudu, ktorý neraz zrazí na kolená aj tých najmocnejších (List 238). V liste pre svojho bývalého spolubrata Eugena III. sa svätý Bernard pokúsil zhrnút tieto predpoklady, ktoré dodávajú pápežskej inštitúcii kredit. Ako biskup sveta (orbis Episcopum) a držitel jedinečného primátu (unici primatus) musí vediet' správne zasiahnut', kedy pliet’ alebo sadit', kedy ničit alebo stavat'. Mocných a pyšných treba zosadit a chudobných a pokorných pozdvihnút, hladných nasýtit' (List 240). ${ }^{12}$

Problémom, ktorý zamestnával generácie cirkevných spisovatelov, panovníkov i samotných rímskych biskupov, bola otázka pápežského primátu. Zložitá problematika, ktorá vyvolávala spory už od ranokrestanských čias, bola Rímom vykladaná ako nespochybnitel’né právo pápeža na nielen čestné, ale aj faktické prvenstvo medzi všetkými biskupmi krestanského sveta. ${ }^{13}$ Svätý Bernard má aj v tejto otázke jasno a okrem už spomínaných ohraničení a požiadaviek, vystupuje ako zástanca primátu so všetkými jeho dôsledkami. V liste pre Milánčanov z roku 1135 píše:

Ak jej preukážete úctu, ktorá jej náleží, bude to úcta bezvýhradná, pretože Apoštolská stolica, vd’aka jedinečnému privilégiu, je obdarená plnou autoritou nad všetkými cirkvami sveta. Každý, kto odporuje tejto autorite, nastavuje tvár proti Božím ustanoveniam. Ona môže, ak to považuje za vhodné, určit nových biskupov tam, kde dovtedy žiadni neboli. Z tých, ktorí už existujú, môže zosadit niektorých a iných zase povýšit tak, ako to považuje za najlepšie; teda ak to pokladá za potrebné, môže vyzdvihnút biskupov na arcibiskupov alebo naopak. Môže zvolávat duchovných, nezávisle na tom, ako sú mocní a vznešení, z konca sveta a priviest' ich $k$ sebe, a to nie raz alebo dva razy, ale tak často, ako to uváži za potrebné. Navyše je rýchla $v$ trestaní neposlušnosti, ak by sa niekto pokúsil odporovat jej prianiam. (List 131) $)^{14}$

10 „Papae permissio licitum facere valuit, quod purum malum fuit.“ List 7, pochádza z roku 1125. Do popredia tu vystupuje Bernardovo učenie o láske (charitas) a dobre ako najvyšších morálnych príkazoch.

11 „Nec enim Deus ubi ait, Nolite contemnere unum ex iis pusillis qui in me credunt; addidit etiam, Nisi cum licentia“.

12 List z roku 1145 alebo 1146 má slúžit novozvolenému pápežovi ako krátky náčrt jeho povinností. Ilustruje však aj Bernardove osobné názory.

13 Dobrý prehlad o tejto téme poskytuje práca Klausa Schatza (2002, najmä 95-97).

14 „Esto, fac quod dicis; quia si exhibeas debitam, et omnimodam. Plenitudo siquidem potestatis super universas orbis Ecclesias, singulari praerogativa apostolicae Sedi donata est. Qui igitur huic potestati resistit, Dei ordinationi resistit. Potest, si utile judicaverit, novos ordinare episcopatus, ubi hactenus non fuerunt. Potest eos qui sunt, alios deprimere, alios sublimare, prout ratio sibi dictaverit, ita ut de episeopis creare archiepiscopos liceat, et e converso, si necesse visum fuerit. Potest a finibus terrae sublimes quascunque 
Posledná veta je venovaná konkrétne milánskej cirkvi, živenej silnou ambrózianskou tradíciou $^{15}$, ktorá sa už od antiky usilovala o nezávislost’ od Ríma, z čoho pramenili početné vzájomné konflikty.

Sila a autorita jedinečného postavenia Petrovho nástupcu zaručuje, že je útočiskom chudobných a slabých pred zlom silných, čo dodáva jeho primátu zvláštne opodstatnenie. Podla Bernarda je najvzácnejším drahokamom v pomyselnej korune pápežských cností túžba po dobre a pomoci utláčaným (List 198). ${ }^{16}$ Človek v tejto funkcii teda musí byt' zaneprázdnený starostou o cirkev, stat' sa jej múrom voči prenasledovatelom a zároveň jej mečom pripraveným kedykolvek zasiahnut na obranu.

Opát z Clairvaux úprimne usiloval o zachovanie vysokého morálneho postavenia rímskej kúrie a nebola mu lahostajná žiadna udalost’ s ňou spojená. V pápežovi videl garanta zachovania pokoja a krestanského poriadku na zemi, a preto považuje každé poškodenie kúrie za svoje vlastné (Romanae curiae injuriam a me non judico alienam). Z tohto dôvodu neváhal zdvihnút hlas a napomenút Svätú stolicu, ked' niekedy posielala tajné listy, ktoré boli v rozpore s jej oficiálnou doktrínou, pretože tým konala proti charitas a stávala sa terčom posmechu pre okolie (List 236). V jednom zo svojich prvých listov smerujúcich do Ríma otvorene píše, že „problémy cirkvi budú trvat dovtedy, dokým bude rímska kúria vynášat rozhodnutia na úkor neprítomných preto, aby sa zapáčila tým, ktorí sú práve po ruke"(List 48). ${ }^{17}$ Apeluje taktiež na čestnost. V prípade, že pápež vydal rozhodnutie, ktoré sa neskôr ukáže ako nesprávne alebo vynútené, nesmie sa hanbit ho odvolat’ a zjednat nápravu. Dobrý úmysel a túžba po dobre sú jednoducho nadradené akýmkolvek kánonom, predpisom či postranným záujmom. Týmto spôsobom chcel Bernard z Clairvaux taktiež prispiet’ $\mathrm{k}$ formovaniu určitého dokonalého pápeža, ktorý by bol pre ludí skôr milujúcim a starostlivým otcom, než prísnym a mocným panovníkom. Počas svojho verejného pôsobenia mal dostatok príležitostí uviest' tieto myšlienky do praxe. ${ }^{18}$

\section{Ochranca pápežstva v turbulentných časoch}

Zo šiestich pápežov, ktorí sa vystriedali na Petrovom stolci počas jeho verejného pôsobenia, nadviazal opát z Clairvaux najväčšie i najúprimnejšie kontakty s Inocentom II. (1130 - 1143), ktorého prakticky pápežom „urobil“ a s Eugenom III. (1145 - 1153), ktorého zase duchovne formoval a učil. Jeho vplyv na týchto (ale aj ostatných) rímskych biskupov bol nespochybnitelný, i ked' ich vztahy neboli vždy jednoduché. Dlhé roky strávil v poslušnej službe pre kúriu, no dokázal zároveň presadit u nej svoje názory a riešenia mnohých problémov. Prvým priamym kontaktom s pápežstvom bolo jeho povolanie na obhajobu Inocenta II. počas schizmy v rokoch 1130 - 1138 (Jedin 2000, 4846-4854).

V noci na 14. februára 1130 zomrel v Ríme pápež Honorius II. a skôr než bolo jeho telo pochované, boli už zvolení dvaja jeho nástupcovia. Ráno v Lateráne kardinál Haimeric presadil volbu kardinála-diakona Gregora zo S. Angela za pápeža Inocenta II. Väčšina kardinálskeho zboru však

personas ecclesiasticas evocare, et cogere ad suam praesentiam, non semel aut bis, sed quoties expedire videbit. Porro in promptu est ei omnem ulcisci inobedientiam, si quis forte reluctari conatus fuerit."

15 Milánsky arcibiskup sv. Ambróz (4. stor.) bol rešpektovanou cirkevnou autoritou, mentorom pápežov a cisárov a zakladatel’ silného postavenia milánskej cirkvi v Itálii (Franzen 2006, 74-75).

16 Adresovaný pápežovi Inocentovi II.

17 „Si non cesset Romana curia pro voluntate assistentium facere praejudicium in absentes. “ List bol adresovaný pápežskému kancelárovi, kardinálovi Haimericovi okolo roku 1130.

18 Podrobnejšiu analýzu vzţahu sv. Bernarda s pápežstvom podáva Joseph Calmette (1979, 56-87), Pierre Aubé (2003, 455-461) a Adriaan H. Bredero (1996, 128-139). 
zvolila o niekolko hodín neskôr Pietra Pierleoniho, pápežským menom Anakleta II. (Vita Prima II. 1, PL 1853; Davy 2001, 50). Obaja pápeži pochádzali z mocných rímskych rodín. Inocent z rodu Papareschi z Trastevere a Anaklet z konvertovanej židovskej rodiny Pierleoniovcov (Jedin 2000, 4848). ${ }^{19}$ Tento spor je teda považovaný aj za súboj staršej generácie reformátorov okolo Anakleta a mladšej generácie snažiacej sa získat’ vplyv okolo Inocenta (Barraclough 1968, 101).

Vojenská, finančná i diplomatická prevaha Anakletových stúpencov donútila Inocenta opustit’ Rím a stiahnut sa do Pisy. Teraz si kúria spomenula na horlivého opáta z Clairvaux a všemožne sa ho snažila získat do svojich služieb. Inocent musel získat' na svoju stranu podporu cirkvi a panovníkov v okolitých krajinách, preto sa vydal do Francúzska. Na koncile v Étampes boli zhromaždení najvýznamnejší biskupi a opáti a podla prameňov sa po počiatočnom váhaní pridali na stranu Inocenta práve po presviedčaní opáta z Clairvaux (Vita Prima II.3, PL 1853; Aubé 2003, 218-238). Podobným spôsobom sa mu podarilo získat na pápežovu stranu aj francúzskeho krála Ludovíta VI., anglického krála Henricha I., nemecký episkopát a neskoršieho cisára Lotara III. ${ }^{20}$ donútil k uskutočneniu rímskej jazdy. Tá sa konala roku 1132/1133 a vdaka nemeckým vojskám mohol Inocent na čas zaujat stratené pozície v Ríme a v júli 1133 korunovat Lotara na cisára v Lateráne. Odchod Lotarových armád znamenal aj odchod Inocentovej skupiny, lebo neboli schopní udržat pozície proti stále silnému Anakletovi. Nový vynútený exil v Pise využil Inocent na zvolanie synody (30.5. - 6.6. 1135), na ktorej sa zúčastnili biskupi z celého Západu, a na ktorej sa znovu prejavila dominantná povaha Bernarda z Clairvaux, ktorý sa tam stal ústrednou osobnostou (Vita Prima II. 8, PL 1853; Thomas 1984, 131-186). Klúčom k ovládnutiu severnej Itálie však bolo Miláno, ktoré stálo na strane Anakleta. Bernard však prijal aj túto výzvu a po dlhých dňoch kázní a „robenia zázrakov“ nakoniec za ovácií Milánčanov priniesol do Pisy spojenectvo tohto večne nepriatel'ského mesta. Nadšení obyvatelia mu dokonca ponúkali milánsky arcibiskupský stolec. ${ }^{21}$ Ani nová výprava Lotara však nepriniesla rozhodnutie, lebo Anaklet sa spojil s mocným sicílskym panovníkom Rogerom II. Ten pripravil Bernardovi d’alšiu výzvu, ked’ mu navrhol, aby sa stretol v teologickej dišpute s vyhláseným myslitel’om a rečníkom Petrom z Pisy, stojacim na pozíciách Anakleta. Bernard, vedomý si Petrovej teologickej prevahy, sa rozhodol na stretnutí v Salerne (1137) použit silu svojej osobnosti a presviedčací talent, vdaka ktorému získal aj tohto protivníka do tábora Inocenta (Vita Prima II. 45-46, PL 1853; Calmette, 1979, 75-76).

Schizma trvajúca osem rokov sa nakoniec skončila smrtou Anakleta na začiatku roku 1138. Inocent sa mohol vrátit’ do Večného mesta, Bernard do svojho tichého opátstva v Clairvaux. Opátova prestíž a sláva počas týchto rokov stúpla natol'ko, že sa stal prirodzenou autoritou v rozhodovaní všetkých cirkevných záležitostí, radcom biskupov aj králov a duchovným vodcom mníšskej reformy. Bernard si z Itálie privádza okrem triumfu aj nadaného mnícha Bernarda z Pisy, ktorý zohrá dôležitú úlohu v jeho živote i v dejinách pápežstva (McGuire 2011, 51).

Vypuknutie schizmy na jar roku 1130 rozdelilo Európu a hlavne jej cirkev na dva tábory. Postupom času (aj vd’aka energickému a neustálemu úsiliu Bernarda) sa na Inocentovu stranu priklonila väčšina kardinálov, biskupov, opátov, ako aj panovníkov a ludu. Proti pápežovi Anakletovi zachovali vernost̉ len niekol'kí talianski kardináli, panovník Roger Sicílsky a akvitánsky episkopát

19 Obidve volby boli uskutočnené za vel’mi nejasných okolností na hranici legálnosti. Z toho vznikli dlhodobé spory o platnosti týchto volieb. Kanonickejšou z oboch sa však zdá byt skôr volba Anakleta. Kardinálovi Haimericovi dalo vela práce, aby dosiahol úplné uznanie svojho počínania.

20 Ten svoju podporu podmieňoval získaním úplného investitúrneho práva, no na koncile v Liége ho Bernard z Clairvaux rázne proti tomu napomenul (Vita Prima II. 5, PL 1853).

21 Bernard bol v tejto otázke neoblomný. Okrem milánskeho stolca odmietol i post biskupa v Langres, Janove a Châlons-sur-Marne či arcibiskupskú hodnost’ v Remeši (Vita Prima, II. 9-12, 26, PL 1853). 
pod autoritou biskupa Gerárda z Angoulême. Práve tých bolo treba presvedčit', aby bolo uznanie pontifikátu Inocenta II. v cirkvi úplné.

Uprostred tejto situácie sa opát z Clairvaux snažil dokázat morálnu prevahu svojho kandidáta v listoch pre akvitánskych klerikov. ${ }^{22}$ Pápež Inocent je predstavený ako Bohom a lud’mi vyvolený služobník, ktorého neprajníci sú Antikristovými sluhami. Prenasledovaním Inocenta sú prenasledovaní všetci nevinní ludia (innocentiam), no a jeho útek z Ríma pred Anakletovým vojskom je prirovnaný k úteku apoštola Pavla $(S k$ 9,25). Tým, že trpel útekom ako apoštoli, dokázal Inocent, že sám je apoštolom (List 124). ${ }^{23} \mathrm{~A} v$ skutočnosti, že zutekal, Bernard vôbec nevidí potupu, lebo ked' „Lev reve, kto by sa nebál?“(List 124). ${ }^{24}$

Anakletovi nemôže príst’ svätec na meno, a preto ho nazýva príšerou z Apokalypsy (Bestia de Apocalypsi), ktorá okupuje Petrov stolec ako lev čakajúci na svoju koriste. Jediný, kto ho nazýva pápežom, je Gerárd z Angoulême, avšak len preto, že sa tak stal jeho legátom. Cirkevný predpis však hovorí jasne, že po prvej volbe už nemôže nasledovat druhá: Stat quippe sententia ecclesiastica et authentica, post primam electionem non esse secundam (List 126). Taktiež jeho podpora je takmer nulová, pretože Inocenta prijali za biskupa svojich duší panovníci vo Francúzsku, Nemecku, Anglicku, Škótsku, Španielsku i v Jeuzaleme s celým svojím klérom a ludom.

Svoje hlavné argumenty v prospech Inocenta uvádza Bernard vo všetkých spomínaných listoch až na záver:

Trojitý povraz sa nedá lahko roztrhnút a volba najlepšími, schválenie viacerými a hlavne (čo je najúčinnejšie) potvrdenie čistých mravov, spoločne odporúčajú všstkým Inocenta a bezpochyby ho ustanovujú za najvyššieho velkňaza (List 124). ${ }^{25}$

Alebo inými slovami ho teda cirkev podporuje, lebo vie, že jeho povest' je čestnejšia, jeho volba rozumnejšia a jeho podporovatelia prevážia počtom i vznešenostou, a v neposlednom rade pre konsekráciu biskupom z Ostie. ${ }^{26}$

Ďalšou výzvou pre opáta z Clairvaux bol konflikt medzi Rimanmi a pápežom Eugenom III., ktorého na popud Arnolda z Brescie vyhnali z mesta. ${ }^{27}$ Nespokojným obyvatelom bolo treba vysvetlit, že ich údelom je bývat’ v sídle Petrovho nástupcu a že bez neho stráca mesto svoju výnimočnost́. Pretože ked' bolí hlava, tak trpí celé telo, tak aj ked je pápežovi robené násilie, zákonite tým trpí celá cirkev. ${ }^{28} \mathrm{~V}$ osobe Eugena vyhnali svojich patrónov sv. Petra a Pavla a pohnevali si samotného Boha. Zosmiešnili sa pred celým svetom, ked' prišli o prítomnost̉ nástupcu apoštolov a z Ríma urobili ovdovené mesto bez hlavy. Tak, ako v prípade Milánčanov nabáda neposlušných obyvatelov, aby sa rýchlo vrátili na správnu cestu a neprivolali na seba zbytočne hnev Boží (v obidvoch prípadoch nakoniec meštania na svoje spurné správanie doplatili). Naopak, protikladom k týmto mestám bola pre cistercitského opáta Pisa, kam sa Inocent II. počas schizmy uchýlil. Mesto bolo v tomto období Bohom obdarené a povýšené na štatút Ríma a baštu Svätej stolice (List 130). ${ }^{29}$

22 List 124 pre Hildeberta, arcibiskupa z Tours, list 125 Geoffreyho z Loreta a list 126 pre akvitánskych biskupov pochádzajú z rokov 1131 - 1132 .

23 „Fugit, et in hoc vere virum se apostolicum probans, quod apostolica sese forma insignierit.“

24 „Leo rugiet, quis non timebit?“ Narážka na Anakletovo rodové meno Petrus Leonis. Porovnaj Am 3, 8.

25 „Funiculus triplex difficile rumpitur. Electio meliorum, approbatio plurium, et, quod his efficacius est, morum attestatio, Innocentium apud omnes commendant, summum confirmant pontificem."

26 Argumenty uvádzané v listoch 125 a 126. Biskup z Ostie podla tradície vysväcoval pápežov po ich zvolení.

27 O Arnoldovi a jeho počínaní v Ríme pozri Brosse (1995, 746-749); Evans (2000, 18).

28 Celý nasledujúci odsek podla listu 243 adresovaného priamo Rimanom v roku 1146.

29 V Pise sa konal aj vel'ký koncil biskupov Západu. List pochádza z vrcholného obdobia schizmy, teda okolo roku 1135. 
Vo svojej korešpondencii sa Bernard len okrajovo venuje vztahu rímskeho biskupa a cisára. V každom prípade aj v tejto otázke má mierne navrch pápež a od panovníka sa očakáva, že bude „preukazovat úctu najvyššej a Apoštolskej stolici a vikárovi sv. Petra presne tak, ako by si to želal pre seba v celej ríši (in exhibenda reverentia summae et apostolicae Sedi, et beati Petri Vicario, sicut ipsam vobis vultis ab universo servari imperio "“( List 183). ${ }^{30}$

V otázke vztahu a právomoci pápeža voči rehol’ným rádom tvrdil, že mnísi majú byt’ plne oddaní a poslušní voči pápežovým prianiam a nariadeniam. Tieto nároky však nesmú odporovat Biblii, Benediktovej reholi a snahe mníchov po charitas. Konkrétnym príkladom môže byt' napríklad volba generálneho opáta v Citeaux, ktorú cisterciti uskutočnili slobodne medzi sebou. Bernard z Clairvaux už len dodatočne informuje pápeža o tomto čine a prosí ho o formálne potvrdenie ich volby posvätením (List 270). ${ }^{31}$

\section{Vplyv vo Večnom meste a vzt’ahy s pápežmi}

Sv. Bernard si postupne uvedomoval, že jeho konanie môže ovplyvňovat' správanie pápežov. Dokázal k tomu využit svoje vel’mi dobré kontakty v kúrii, ale aj svoj presviedčací talent. Vystihujú to napríklad jeho zásluhy na presadení Inocenta II. počas schizmy alebo dlhodobý vplyv na „cistercitského“ pápeža Eugena III. Bernard však nikdy nepocitoval potrebu hierarchického postupu či ovládania kohokolvek. Jeho osobnost’ a vysoký morálny kredit mu však umožňovali dovolit si trochu viac, ako by sa dalo očakávat.

Obrovský počet opátových listov smeroval do rímskej kúrie s rôznymi žiadostami, prosbami či dokonca nariadeniami. Bernard orodoval za svojich priatelov i neznámych ludí rôzneho postavenia, ktorí sa naňho obracali, lebo vedeli, že len tak ich v Ríme vypočujú. To sú napríklad prípady odporúčacích listov pre Sugera zo St. Denis, clunyjského opáta Petra Ctihodného či Jána zo Salisbury, pre ktorých žiadal pomoc u pápežov. ${ }^{32}$

O tom, že jeho prosby (či pripomienky) mali v Ríme úspech svedčia prípady, ked’ roku 1136 píše pápežovi Inocentovi, ktorý práve menoval svätcovho priatela Bernarda z Portes biskupom v Pavii, že by bolo lepšie, ak ho preloží na iné miesto, čo sa nakoniec aj stalo (List 155). V roku 1150 si Eugen III. povolal do Ríma biskupa z Beauvais, ktorého si však Bernard dovolil zadržat’ vo Francúzsku s odôvodnením, že mu nebolo celkom jasné, prečo tam má íst' (List 305). ${ }^{33}$ To, že Eugen nemal problém s plnením prianí svojho vplyvného učitela dosvedčuje aj krátky list, $\mathrm{v}$ ktorom proste dostáva pokyny, ako zasiahnut v rôznych záležitostiach v prospech Bernardových blízkych i jemu celkom cudzích ludí (List 284).

V prípade, že sa veci vyvíjali odlišne od jeho predstáv, dáva to opát z Clairvaux najavo. Po vyslovení svojho rozhorčenia Eugenovi doslova nedáva na výber a píše, že nemôže už urobit nič iné, len odvolat svoje predošlé rozhodnutie (List 268).

$\mathrm{Na}$ druhej strane nešetrí sv. Bernard pri dobrých skutkoch slovami chvály a povzbudenia. Sám seba ponižuje do úlohy syna, lebo autoritu otca prenechal Eugenovi, a s vdačnostou poslúcha toho, kto môže prikazovat, komu chce a čo chce. A kedže to robí dobrovolne, už viac nie je služobníkom ale poslušným synom (List 258 a 259). Na dokázanie svojho citového vztahu k pápežovi opát

30 Nemeckému královi Konrádovi III. z roku 1139.

31 Pápežovi Eugenovi III. z roku 1151.

32 Listy 309,277 a 361.

33 „Quod autem retinere volui, cum multae occurrerent causae, illud praecipuum fuit, quod de vestra dubitavimus voluntate.“ 
z Clairvaux vyhlasuje, že „čokolvek, čo poškvrní dobré meno môjho najdrahšieho pána raní moje srdce (Quidquid dulcissimi domini mei nomen decolorat, cor meum excoriat)" (List 179). ${ }^{34}$

Teoreticky sa vrcholom kariéry Bernarda z Clairvaux stáva rok 1145, ked’ sa naplńa jeho celoživotný sen o christianitas riadenej cistercitským mnišstvom. V tom roku sa totiž pápežom stáva Bernardov priatel' a bývalý mních z Clairvaux Bernard z Pisy, ktorého si tam opát priviedol počas pôsobenia v Itálii, a ktorý prijíma meno Eugen III. (Oldenbourg 1982, 81). V skutočnosti však išlo možno viac o prejav rešpektu voči samotnému Bernardovi, lebo už súčasníci vraveli, že on je pravým pápežom a Eugen je len hračkou v jeho rukách. ${ }^{35} \mathrm{~V}$ každom prípade sa opát z Clairvaux k nemu správal tak, ako ku všetkým ostatným pápežom - radil mu, nabádal ho a prikazoval mu, čo má robit' (Listy 238, 239, 276, 282, 284, 305).

\section{Záver}

Jedinečné a významné postavenie medzi všetkými biskupmi mal biskup rímsky. Ako priamy nástupca svätého Petra mal pápež, sídliaci v bývalom hlavnom meste sveta, teoretické i praktické nároky na spočiatku čestný, neskôr už skutočný primát medzi krestanskými biskupmi. Opát z Clairvaux bol zástancom tohto primátu a po celý život bol naklonený pápežskej politike, v ktorej sa často angažoval.

Ako najvyšší predstavitel' a hlava celého krestanstva, ktorý svoju úlohu a moc odvodzoval priamo od poverenia samotným Kristom (Mt 16,18-19), musel na seba prevział obrovskú zodpovednost' a starosti. A tu sa nám vynára predstava ideálneho pápeža, ktorú svätý Bernard formuluje vo svojej korešpondencii. Najvernejším biblickým vzorom mu je tak, ako aj v iných otázkach, starozákonný král' Dávid. Pápež však nemá vystupovat ako bojovník a prísny sudca, ale ako milujúci otec a ochranca, ktorý je oporou pre svoj lud (Listy 237 a 238). Bohužial', pevný a čistý charakter, patričné vzdelanie, ochota zostat i v tomto postavení poníženým služobníkom Božím, spojené s chudobou, boli väčšinou len predstavou v myšlienkach clairvauxského opáta. V skutočnosti musel pápežov často napomínat a pripomínat im ich úlohy a dodržiavanie krestanských životných pravidiel. Vdaka pozornému dohladu a neustálemu prúdu listov majúcich napomenút a napravit’ ich poklesky, sa Bernardovi zväčša podarilo zamedzit pápežom v nejakých velkých excesoch alebo pohoršlivých skutkoch, ich previnenia sa obmedzili na drobnejšie prehrešky. Toto počínanie a rétorika použitá $\mathrm{v}$ predložených listoch spôsobuje niekedy dojem akoby tento opát stál hierarchicky nad pápežmi. To bolo, samozrejme, možné len za cenu toho, že už nemohol žit v ideálnom svete kontemplatívneho mnícha odrezaného od okolitého sveta. Sám Bernard to napokon velmi dobre vedel. V jednom zo svojich najznámejších listov sám seba opisuje ako bájnu bytost' zloženú z viacerých stvorení: „Som akousi modernou chimérou, lebo už nie som ani klerikom, ani laikom. Ponechal som si šat mnícha, no už dávno som opustil život“ (List 326; McGuire 2011, 41).

\section{REFERENCES}

Aubé, Pierre. 2003. Saint Bernard de Clairvaux. Paris.

Barber, Malcom. 1993. The Two Cities. Medieval Europe 1050-1320. London-New York. Barraclough, Geoffrey. 1968. The Medieval Papacy. London.

34 Pápežovi Inocentovi II.

35 Priznáva to sám Bernard v liste adresovanom práve Eugenovi: „Aiunt non vos esse Papam, sed me“ (List 239). K tomu pozri Verger - Jolivet $(2006,183)$. 
Bartlett, Robert. 1994. The Making of Europe. Conquest, Colonization and Cultural Change 950 1350. London.

Béguin, Albert. 1953. Oevres mystiques de Saint Bernard. Paris.

Bredero, Adriaan H. 1996. Bernhard von Clairvaux. Zwischen Kult und Historie. Stuttgart.

Brosse, Jacques. 1995. Histiore de la Chrétienté d'Orient et d'Occident, Paris.

Calmette, Joseph. 1979. Saint Bernard. Paris.

Collins, Roger. 2009. Keepers of the keys of heaven: a history of the papacy. New York.

Davy. Marie-Madeleine. 2001. Bernard de Clairvaux. Paris.

Duby, George. 1979. Saint Bernard et l'art cistercien. Paris.

Evans, G. R. 2000. Bernard of Clairvaux. Oxford.

Franzen, August. 2006. Malé dějiny církve. Kostelní Vydří.

Frizot, Julien - Perrin, Thierry. 2006. Sur les pas de Bernard de Clairvaux et des Cisterciens. Rennes.

Hehl, Ernst-Dieter - Ringel, Ingrid Heike - Seibert, Hubertus (eds.). 2002. Das Papsttum in der Welt des 12. Jahrhunderts. Stuttgart.

James, Bruno Scott (ed.). 1998. The Letters of St. Bernard of Clairvaux. Kalamazoo.

Jedin, Hubert. 2000. Handbuch der Kirchengeschichte. Digitale Bibliothek Band 35. Berlin.

Leclercq, Jean. 1998. St. Bernard et l'esprit cistercien. Paris.

Leclercq, Jean - Talbot, Charles-Hugh - Rochais, Henri (eds.), 1957 - 1958. Sancti Bernardi Opera.

Editiones citercienses. Roma.

Le Goff, Jacques. 1985. Les intellectueles au Moyen Age. Paris.

McGuire, Brian Patrick (ed.). 2011. A companion to Bernard of Clairvaux. Leiden-Boston.

Migne, Jacques-Paul (ed.). 1854 - 1855. S. Bernardi Opera Omnia. Patrologiae cursus completus. Series latina. Tom. 182-185. Paris.

Oldenbourg, Zoé. 1982. Saint Bernard. Paris.

Sayers, Jane. 1994. Innocent III. Leader of Europe 1198 - 1216. London-New York.

Schatz, Klaus. 2002. Dějiny papežského primátu. Brno.

Thomas, Robert 1984. Vie de Saint Bernard. Dijon.

Verger, Jacques - Jolivet, Jean. 2006. Le siècle de saint Bernard et Abélard. Paris.

Vita Prima PL 1853. Migne, Jacques-Paul. (ed). Patrologiae cursus completus. Series latina. Tomus 185. Paris.

Mgr. Dušan Zupka, PhD.

Comenius University Bratislava

Faculty of Arts

General History Department

Gondova 2

81102 Bratislava

Slovakia

dusan.zupka@uniba.sk 


\section{Príloha / Appendix}

Tabela 1. Listy Bernarda z Clairvaux adresované pápežom $1124-1153 .{ }^{36}$

Table 1. Letters of Bernard of Clairvaux addressed to popes between 1124 and 1153.

\begin{tabular}{|c|c|c|}
\hline List & Adresát & Dátum \\
\hline 5 & Kalixtus II. & $1124 / 1125$ \\
\hline 14 & Honorius II. & 1126 \\
\hline 15 & Honorius II. & $1128 / 1129$ \\
\hline 49 & Honorius II. & 1129 \\
\hline 50 & Honorius II. & 1129 \\
\hline 52 & Honorius II. & 1129 \\
\hline 53 & Honorius II. & 1129 \\
\hline 137 & Inocent II. & 1135 \\
\hline 149 & Inocent II. & 1134 \\
\hline 155 & Inocent II. & 1133 \\
\hline 156 & Inocent II. & 1133 \\
\hline 158 & Inocent II. & 1135 \\
\hline 161 & Inocent II. & 1136 \\
\hline 162 & Inocent II. & 1136 \\
\hline 164 & Inocent II. & 1133 \\
\hline 165 & Inocent II. & 1134 \\
\hline 179 & Inocent II. & 1138 \\
\hline 181 & Inocent II. & 1138 \\
\hline 182 & Inocent II. & 1138 \\
\hline 185 & Inocent II. & 1138 \\
\hline 187 & Inocent II. & 1142 \\
\hline 188 & Inocent II. & 1142 \\
\hline 202 & Celestín II. & 1143 \\
\hline 204 & Lucius II. & 1144 \\
\hline 205 & Eugen III. & 1145 \\
\hline 206 & Eugen III. & 1145 \\
\hline 207 & Eugen III. & 1145 \\
\hline 208 & Eugen III. & $1146 / 1147$ \\
\hline 209 & Inocent II. & $1139 / 1140$ \\
\hline 211 & Inocent II. & 1139 \\
\hline 213 & Inocent II. & 1139 \\
\hline 218 & Inocent II. & 1135 \\
\hline 220 & Inocent II. & 1140 \\
\hline 221 & Inocent II. & 1140 \\
\hline 222 & Inocent II. & 1140 \\
\hline 227 & Inocent II. & 1140 \\
\hline
\end{tabular}

${ }_{36}$ Č́slovanie listov podla edície James, Bruno Scott (ed.). 1998. The Letters of St. Bernard of Clairvaux. Kalamazoo. 


\begin{tabular}{|c|c|c|}
\hline 239 & Inocent II. & 1140 \\
\hline 242 & Inocent II. & 1140 \\
\hline 252 & Inocent II. & 1141 \\
\hline 254 & Inocent II. & 1141 \\
\hline 255 & Inocent II. & 1141 \\
\hline 258 & Inocent II. & 1143 \\
\hline 264 & Inocent II. & $1138-1143$ \\
\hline 265 & Inocent II. & $1138-1143$ \\
\hline 266 & Inocent II. & $1138-1143$ \\
\hline 267 & Inocent II. & $1138-1143$ \\
\hline 268 & Inocent II. & $1138-1143$ \\
\hline 269 & Inocent II. & $1138-1143$ \\
\hline 280 & Inocent II. & 1140 \\
\hline 281 & Inocent II. & 1141 \\
\hline 282 & Inocent II. & 1143 \\
\hline 283 & Inocent II. & 1139 \\
\hline 284 & Inocent II. & 1140 \\
\hline 285 & Inocent II. & 1140 \\
\hline 286 & Inocent II. & $1141 / 1142$ \\
\hline 287 & Inocent II. & $1141 / 1142$ \\
\hline 288 & Inocent II. & 1143 \\
\hline 289 & Inocent II. & 1143 \\
\hline 290 & Inocent II. & $1138-1143$ \\
\hline 291 & Inocent II. & $1138-1143$ \\
\hline 292 & Inocent II. & 1143 \\
\hline 294 & Inocent II. & 1142 \\
\hline 295 & Inocent II. & 1143 \\
\hline 304 & Celestín II. & 1143 \\
\hline 314 & Eugen III. & 1145 \\
\hline 321 & Eugen III. & 1145 \\
\hline 322 & Eugen III. & 1146 \\
\hline 323 & Eugen III. & 1146 \\
\hline 324 & Eugen III. & $1146 / 1147$ \\
\hline 325 & Eugen III. & 1146 \\
\hline 327 & Eugen III. & 1147 \\
\hline 330 & Eugen III. & 1150 \\
\hline 331 & Eugen III. & $1145-1148$ \\
\hline 332 & Eugen III. & $1145-1148$ \\
\hline 334 & Eugen III. & 1151 \\
\hline 335 & Eugen III. & $?$ \\
\hline 337 & Eugen III. & 1147 \\
\hline 338 & Eugen III. & 1148 \\
\hline 339 & Eugen III. & $1149-1152$ \\
\hline 340 & Eugen III. & 1151 \\
\hline
\end{tabular}




\begin{tabular}{|l|l|l|}
\hline 343 & Eugen III. & 1152 \\
\hline 345 & Eugen III. & 1152 \\
\hline 346 & Eugen III. & 1152 \\
\hline 347 & Eugen III. & 1152 \\
\hline 349 & Eugen III. & 1151 \\
\hline 350 & Eugen III. & 1149 \\
\hline 353 & Eugen III. & 1152 \\
\hline 354 & Eugen III. & $1151 / 1152$ \\
\hline 356 & Eugen III. & $1149-1153$ \\
\hline 359 & Eugen III. & $1150-1153$ \\
\hline 363 & Eugen III. & 1152 \\
\hline 371 & Eugen III. & 1150 \\
\hline 381 & rímsky biskup & 1145 \\
\hline 399 & Eugen III. & 1150 \\
\hline 412 & Eugen III. & 1152 \\
\hline 413 & Eugen III. & 1152 \\
\hline
\end{tabular}

